\title{
Dehumanization of the Invisible, Traumatized and Undocumented Children Incarcerated in the United States: What are the Educational Implications?
}

\author{
Roslin Growe, Ed.D \\ University of Louisiana at Lafayette \\ P. O. Box 43091 \\ Lafayette, LA 70504, USA \\ Charnetta Robinson, Ed.D \\ St. Tammany Parish Public School System \\ Harrison Curriculum Center \\ 706 W. 28th Avenue \\ Covington, LA 70433, USA
}

\begin{abstract}
In April 2018, the United States of America made it lawful to separate children from their families at the US-Mexico border. The adults were jailed and prosecuted for illegal border crossing under a new zero-tolerance policy enacted by the Trump administration, while their children were moved into shelters overseen by the Office of Refugee Resettlement. Supporters of these acts were not considering the physical, psychological and traumatic impacts children will and are suffering as a result of being forcibly separated from their families. The damage inflicted is unimaginable. Over 2,300 migrant children have been separated from their families since May 2018.
\end{abstract}

Keywords: Migrant children, dehumanized children, traumatized children,

\section{The New Face of Dehumanization}

Dehumanization is perceived as the viciousness inflicted on stigmatized groups coupled with the deprivation of morality by which oppressed people are entitled. Though not treated equitably, these individuals are deliberately positioned "outside the boundary in which moral values, rules, and considerations of fairness apply" (Opotow, 1990, p. 1).Referring to historically oppressed and discriminated groups, Haslam( 2006) maintains that "the denial of full humanness to others, and the cruelty and suffering that accompany it, is an all-too familiar phenomenon." (p. 252). He also contends that "dehumanization is just one of several extreme forms of moral exclusion" (p. 254). People who are the aggressors visualize those being dehumanized "no longer ... as persons with feelings, hopes and concerns but as sub-human objects" (Bandura, 2002, p. 109).

Paulo Freire (1981) in Pedagogy of the Oppressed, expresses the struggles of those encased in endorsed savagery as "Dehumanization, which marks not only those whose humanity has been stolen, but also (though in a different way) those who have stolen it, is a distortion of the vocation of becoming more fully human. The struggle [for humanization] is possible only because dehumanization, although a concrete historical fact, is not a given destiny but the result of an unjust order that engenders violence in the oppressors, which in turn dehumanizes the oppressed" (p. 44).

Nick Haslam (2006) describes two forms of dehumanization, "animalistic and mechanistic" (p.260) in Dehumanization: An Integrative Review. Animalistic dehumanization Involves one social group denying that another social group has the same set of uniquely human (UH) attributes as pointed out by Haslam (2006). This type of dehumanization is called animalistic dehumanization because it is often categorized by the unambiguous application to the other social group with that of animalistic characteristics. This form of dehumanization is consistent with the attitudes expressed towards the dehumanized group in earlier social psychological research (Bandura, Underwood, \& Fromson, 1975). Animalistic dehumanization relates to Cudd's theory of group-based oppression (Cudd, 2006).

An example of animalistic dehumanization is the caging and mistreatment of immigrant children. The impact on these children will notably result in being permanently traumatized, with likely irreversible developmental and psychological impacts with "cascading consequences" (p. 68) (Petersen and Feit,2014). Mechanistic dehumanization shows characteristic treatments as: "Inertness, Coldness, Rigidity, Passivity, Fungibility, Superficiality" (Haslam, 2006, p. 257). This type of dehumanization is based on associating the individual to that of a machine. Because of social ineptness, indifference, blatant emotional underdevelopment, lack of empathy, patterns of detachment, and various biases are displayed within this category. 
The individual is equated to that of a robot with unemotional artificial intelligence. A person showing little or no empathy for others falls within this category which is based on the notion they are unable to show concern for those around them (Haslam, p. 206).

\section{Moral Dimensions of Dehumanization}

Herbert Kelman (1976) explored the moral dimensions of dehumanization in the context of sanctioned mass violence, focusing on the conditions under which normal moral restraints on violence are weakened. He maintained that hostility generates violence indirectly by dehumanizing victims, so that no moral relationship with the victim obstructs the victimizer's violent behavior. Kelmansurmised that, dehumanization involves denying a person"identity"-a perception of the person "as an individual, independent and distinguishable from others, capable of making choices" (p. 301) - and "community" - a perception of the other as "part of an interconnected network of individuals who care for each other" (p. 301).

When offenders view the people they mistreat as sub-human treating them cruelly, and inhumanely, these actions align with moral disengagement. Bandura, Underwood, \& Fromson, (1975) described one of the eight forms of moral disengagement as dehumanization.

\section{Legal Questions Relating to Educating Undocumented Children}

There tends to be multiple layers in the journey of immigrant children. Beyond the physical and psychological dilemmas and traumas of these children are the educational concerns. With legislation supporting the rights of undocumented children to a free public-school K-12 education, another battle tends to be brewing which will focus on the rights of these children to free public-school education when or if they are released to reside in the United States. Two legislative actions are recognized regarding undocumented children attending public schools in the United States.

In 1982, the U.S. Supreme Court held that Texas violated the Equal Protection Clause of the Fourteenth Amendment to the Constitution by denying undocumented school-age children a free public education. Undocumented children, according to the Constitution have a constitutional right to receive a free public K-12 education. The rationale was that children are in this country through no fault of their own and are entitled to the same education that the state provides to children who are citizens or legal residents (Borkowski, 2009).

The McKinney-Vento Act provides educational rights to students experiencing homelessness, including unaccompanied youth, regardless of their immigration status. It also provides these youth with the right to enroll in school immediately and without documentation; the right to attend their school of origin even if a temporary living situation is in another school district, including the right to transportation; and the right to attend school without legal guardian or guardianship documents (School House Connection-New Resources, 2018).

\section{Conclusion}

The multidimensional impact of migrant children separated from their parents and caged in unsanitary conditions was explored. Not only are these conditions deplorable but studies have shown that significant cognitive, developmental and psychological effects on these children are interwoven into their mere existence. In addition, the educational disparities that can potentially exist for these groups have been addressed as well as current legal actions that are in place to ensure equity among all children. With the United States already battling mental health issues among young people, this only adds to the complexities centered around addressing this seemingly growing dilemma. Given the complexity of the types of trauma experiences by these children, it is foreseeable that schools, teachers, educational leaders will be forced to address and implement strategies in order to serve these children which has the potential of burdening an already overburdened educational system.

\section{References}

Allison Abrams, LCSW-R. Damage of Separating Families: The psychological effects on children. Psychology Today, June 2018.

Bandura, A. (2002). Selective moral disengagement in the exercise of moral agency. Journal of Moral Education, 31, $101-119$.

Bandura, A. (1999). Moral disengagement in the perpetration of inhumanities. Personality and social psychology review, 33, 193-209.

Bandura, A., Underwood, B., \& Fromson, M. E. (1975). Disinhibition of aggression through diffusion of responsibility and dehumanization of victims. Journal of Research in Personality, 9(4), 253-269. 
Belsky J. Etiology of child maltreatment: A developmental-ecological analysis. Psychological Bulletin. 1993; 114(3):413-434.

Borkowski, John W. 2009. Legal Issues for School Districts Related to the Education of Undocumented Children. Washington, DC: The National School Boards Association and the National Education Association.

Cicchetti D, Lynch M. Toward an ecological/transactional model of community violence and child maltreatment: Consequences for children's development. Psychiatry-Interpersonal and Biological Processes. 1993;56(1):96118.

Cicchetti D, Toth SL. Handbook of child psychology. 5th. Damon W, Sigel IE, Renninger KA, editors. Vol. 4. Hoboken, NJ: John Wiley \& Sons, Inc; 1998. pp. 479-583. Perspectives on research and practice in developmental psychopathology.

Committee on Child Maltreatment Research, Policy, and Practice for the Next Decade: Phase II; Board on Children, Youth, and Families; Committee on Law and Justice; Institute of Medicine; National Research Council; Petersen AC, Joseph J, Feit M, editors, (2014). Washington (DC): National Academies Press (US); 2014 Mar 25.

Cudd, A. E. (2006).Analyzing oppression. New York, NY: Oxford University Press.

Freire, P. (1981). Pedagogy of the oppressed. Chapter one pages 27-37. NY: Continuum.

Education Counsel, (2017). Undocumented Students' Rights of Equal Access to K-12 Education.

Haslam, Nick (2006). Dehumanization: An Integrative Review.Personality and Social Psychology Review 2006, Vol. 10, No. 3, 252-264.

Kelman, H. C. (1976). Violence without restraint: Reflections on the dehumanization of victims and victimizers. In G. M. Kren \& L. H. Rappoport (Eds.), Varieties of psychohistory (pp. 282-314). New York: Springer.

Opotow, Susan, 1990. Moral Exclusion and Injustice: An Introduction.Journal of Social Issues, Volume 46 (1-20) Apr 1, 1990.

School House Connection-New Resources, (2018). McKinney-Vento Act: 2-Page Summary: Homeless Children and Youth in Every Student Succeeds Act of 2015. https://www.schoolhouseconnection.org/mckinney-vento-acttwo-page-summary/. 